\title{
Safe and Effective Bedside Thoracentesis: A Review of the Evidence for Practicing Clinicians
}

\author{
Richard Schildhouse, $\mathrm{MD}^{1,2^{*}}$, Andrew Lai, MD, MPH${ }^{3}$, Jeffrey H. Barsuk, MD, MS ${ }^{4}$, Michelle Mourad, MD², \\ Vineet Chopra, MD, MSc ${ }^{1,2}$
}

\begin{abstract}
${ }^{1}$ Division of General Medicine, Department of Internal Medicine, University of Michigan School of Medicine, Ann Arbor, Michigan; ${ }^{2}$ Division of General Medicine, VA Ann Arbor Healthcare System, Ann Arbor, Michigan; 'BDivision of Hospital Medicine, Department of Medicine, University of California, San Francisco, San Francisco, California; ${ }^{4}$ Department of Medicine, Northwestern University Feinberg School of Medicine, Chicago, Illinois.
\end{abstract}

BACKGROUND: Physicians often care for patients with pleural effusion, a condition that requires thoracentesis for evaluation and treatment. We aim to identify the most recent advances related to safe and effective performance of thoracentesis.

METHODS: We performed a narrative review with a systematic search of the literature. Two authors independently reviewed search results and selected studies based on relevance to thoracentesis; disagreements were resolved by consensus. Articles were categorized as those related to the pre-, intra- and postprocedural aspects of thoracentesis.

RESULTS: Sixty relevant studies were identified and included. Pre-procedural topics included methods for physician training and maintenance of skills, such as simulation with direct observation. Additionally, pre-procedural topics in- cluded the finding that moderate coagulopathies (international normalized ratio less than 3 or a platelet count greater than $25,000 / \mu \mathrm{L}$ ) and mechanical ventilation did not increase risk of postprocedural complications. Intraprocedurally, ultrasound use was associated with lower risk of pneumothorax, while pleural manometry can identify a nonexpanding lung and may help reduce risk of re-expansion pulmonary edema. Postprocedurally, studies indicate that routine chest $X$-ray is unwarranted, because bedside ultrasound can identify pneumothorax.

CONCLUSIONS: While the performance of thoracentesis is not without risk, clinicians can incorporate recent advances into practice to mitigate patient harm and improve effectiveness. Journal of Hospital Medicine 2017;12:266-276. (C) 2017 Society of Hospital Medicine
Pleural effusion can occur in myriad conditions including infection, heart failure, liver disease, and cancer. ${ }^{1}$ Consequently, physicians from many disciplines routinely encounter both inpatients and outpatients with this diagnosis. Often, evaluation and treatment require thoracentesis to obtain fluid for analysis or symptom relief.

Although historically performed at the bedside without imaging guidance or intraprocedural monitoring, thoracentesis performed in this fashion carries considerable risk of complications. In fact, it has 1 of the highest rates of iatrogenic pneumothorax among bedside procedures. ${ }^{2}$ However, recent advances in practice and adoption of newer technologies have helped to mitigate risks associated with this procedure. These advances are relevant because approximately $50 \%$ of thoracenteses are still performed at the bedside. ${ }^{3}$ In this review, we aim to identify the most recent key practices that enhance the safety and the effectiveness of thoracentesis for practicing clinicians.

\footnotetext{
*Address for correspondence and reprint requests: Richard J. Schildhouse, MD, VA Ann Arbor Healthcare System, Department of Internal Medicine (111), 2215 Fuller Road, Ann Arbor, Ml 48105; Telephone: 734-222-8961; Fax: 734913-0883; E-mail: rschildh@med.umich.edu

Additional Supporting Information may be found in the online version of this article.

Received: June 6, 2016; Revised: September 5, 2016; Accepted: September 18, 2016
}

2017 Society of Hospital Medicine DOI 10.12788/jhm.2716

\section{METHODS}

\section{Information Sources and Search Strategy}

With the assistance of a research librarian, we performed a systematic search of PubMed-indexed articles from January 1, 2000 to September 30, 2015. Articles were identified using search terms such as thoracentesis, pleural effusion, safety, medical error, adverse event, and ultrasound in combination with Boolean operators. Of note, as thoracentesis is indexed as a subgroup of paracentesis in PubMed, this term was also included to increase the sensitivity of the search. The full search strategy is available in the Appendix. Any references cited in this review outside of the date range of our search are provided only to give relevant background information or establish the origin of commonly performed practices.

\section{Study Eligibility and Selection Criteria}

Studies were included if they reported clinical aspects related to thoracentesis. We defined clinical aspects as those strategies that focused on operator training, procedural techniques, technology, management, or prevention of complications. Non-English language articles, animal studies, case reports, conference proceedings, and abstracts were excluded. As our intention was to focus on the contemporary advances related to thoracentesis performance, (eg, ultrasound [US]), our search was limited to studies published after the year 2000. Two authors, Drs. Schildhouse and Lai independently screened studies to determine inclusion, excluding studies with weak methodology, very small sample sizes, and those 
only tangentially related to our aim. Disagreements regarding study inclusion were resolved by consensus. Drs. Lai, Barsuk, and Mourad identified additional studies by hand review of reference lists and content experts (Figure 1).

\section{Conceptual Framework}

All selected articles were categorized by temporal relationship to thoracentesis as pre-, intra-, or postprocedure. Pre-procedural topics were those outcomes that had been identified and addressed before attempting thoracentesis, such as physician training or perceived risks of harm. Intraprocedural considerations included aspects such as use of bedside US, pleural manometry, and large-volume drainage. Finally, postprocedural factors were those related to evaluation after thoracentesis, such as follow-up imaging. This conceptual framework is outlined in Figure 2.

\section{RESULTS}

The PubMed search returned a total of 1170 manuscripts, of which 56 articles met inclusion criteria. Four additional articles were identified by experts and included in the study. ${ }^{4-7}$ Therefore, 60 articles were identified and included in this review. Study designs included cohort studies, case control studies, systematic reviews, meta-analyses, narrative reviews, consensus guidelines, and randomized controlled trials. A summary of all included articles by topic can be found in the Table.

\section{PRE-PROCEDURAL CONSIDERATIONS}

Physician Training

Studies indicate that graduate medical education may not adequately prepare clinicians to perform thoracentesis. ${ }^{8}$ In

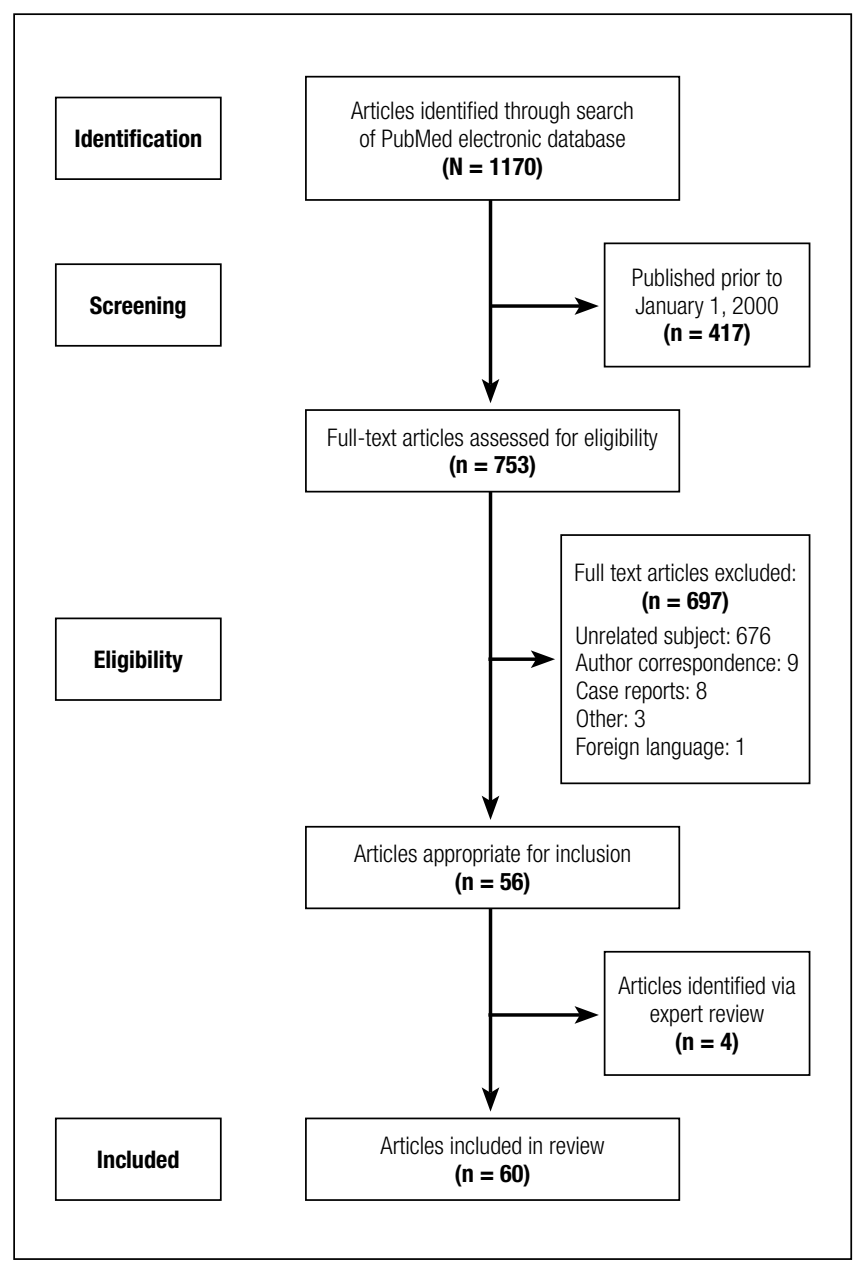

FIG. 1. Study eligibility and selection criteria.

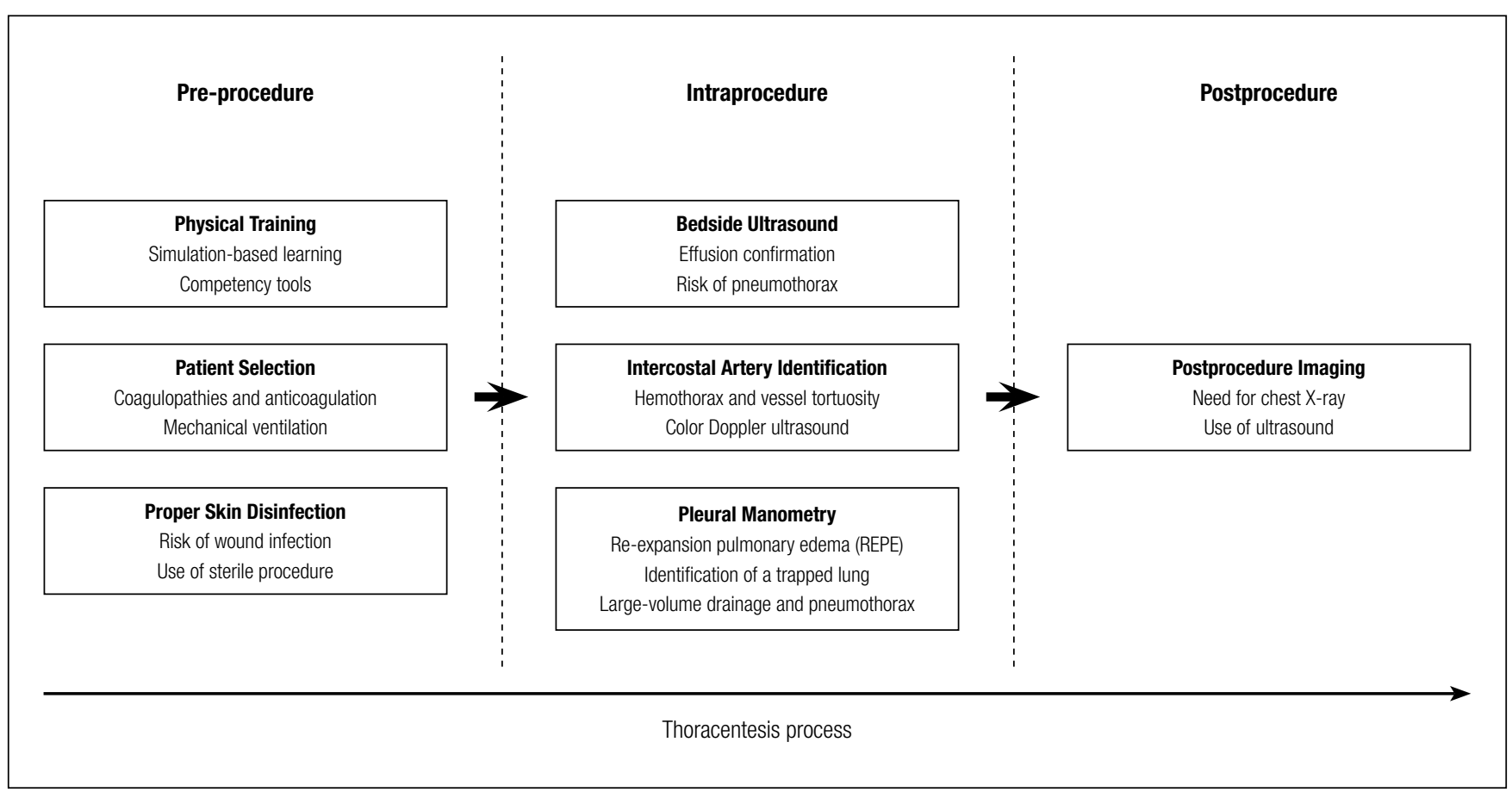

FIG. 2. Conceptual framework. 
fact, residents have the least exposure and confidence in performing thoracentesis when compared to other bedside procedures. ${ }^{9,10}$ In 1 survey, $69 \%$ of medical trainees desired more exposure to procedures, and $98 \%$ felt that procedural skills were important to master. ${ }^{11}$ Not surprisingly, then, graduating internal medicine residents perform poorly when assessed on a thoracentesis simulator. ${ }^{12}$

Supplemental training outside of residency is useful to develop and maintain skills for thoracentesis, such as simulation with direct observation in a zero-risk environment. In 1 study, "simulation-based mastery learning" combined an educational video presentation with repeated, deliberate practice on a simulator until procedural competence was acquired, over two 2-hour sessions. In this study, 40 third-year medicine residents demonstrated a $71 \%$ improvement in clinical skills performance after course completion, with $93 \%$ achieving a passing score. The remaining $7 \%$ also achieved passing scores with extra practice time. ${ }^{12}$ Others have built upon the concept of simulation-based training. For instance, 2 studies suggest that use of a simulation-based curriculum improved both thoracentesis knowledge and performance skills in a 3-hour session. ${ }^{13,14}$ Similarly, 1 prospective study reported that a half-day thoracentesis workshop using simulation and 1:1 direct observation successfully lowered pneumothorax rates from $8.6 \%$ to $1.8 \%$ in a group of practicing clinicians. Notably, additional interventions including use of bedside US, limiting operators to a focused group, and standardization of equipment were also a part of this quality improvement initiative. ${ }^{7}$ Although repetition is required to gain proficiency when using a simulator, performance and confidence appear to plateau with only 4 simulator trials. In medical students, improvements derived through simulator-based teaching were sustained when retested 6 months following training. ${ }^{15}$

An instrument to ensure competency is necessary, given variability in procedural experience among both new graduates and practicing physicians,. Our search did not identify any clinically validated tools that adequately assessed thoracentesis performance. However, some have been proposed ${ }^{16}$ and 1 validated in a simulation environment. ${ }^{12}$ Regarding the incorporation of US for effusion markup, 1 validated tool used an 11-domain assessment covering knowledge of US machine manipulation, recognition of images with common pleural effusion characteristics, and performance of thoracic US with puncture-site marking on a simulator. When used on 22 participants, scores with the tool could reliably differentiate between novice, intermediate, and advanced groups $(P<0.0001) .{ }^{17}$

\section{Patient Selection}

Coagulopathies and Anticoagulation. Historically, the accepted cutoff for performing thoracentesis is an international normalized ratio (INR) less than 1.5 and a platelet count greater than $50,000 / \mu \mathrm{L}$. McVay et al. ${ }^{18}$ first showed in 1991 that use of these cutoffs was associated with low rates of periprocedural bleeding, leading to endorsement in the
British Thoracic Society (BTS) Pleural Disease Guideline $2010 .{ }^{19}$ Other recommendations include the 2012 Society for Interventional Radiology guidelines that endorse correction of an INR greater than 2, or platelets less than 50,000/ $\mu \mathrm{L}$, based almost exclusively on expert opinion. ${ }^{5}$

However, data suggest that thoracentesis may be safely performed outside these parameters. For instance, a prospective study of approximately 9000 thoracenteses over 12 years found that patients with an INR of 1.5-2.9 or platelets of $20,000-49,000 / \mu \mathrm{L}$ experienced rates of bleeding complications similar to those with normal values. ${ }^{20}$ Similarly, a 2014 review ${ }^{21}$ found that the overall risk of hemorrhage during thoracentesis in the setting of moderate coagulopathy (defined as an INR of $1.5-3$ or platelets of $25,000-50,000 / \mu \mathrm{L}$ ), was not increased. In 1 retrospective study of more than 1000 procedures, no differences in hemorrhagic events were noted in patients with bleeding diatheses that received prophylactic fresh frozen plasma or platelets vs. those who did not. ${ }^{22}$ Of note, included studies used a variety of criteria to define a hemorrhagic complication, which included: an isolated $2 \mathrm{~g} / \mathrm{dL}$ or more decrement in hemoglobin, presence of bloody fluid on repeat tap with associated hemoglobin decrement, rapid re-accumulation of fluid with a hemoglobin decrement, or transfusion of 2 units or more of whole blood.

Whether it is safe to perform thoracentesis on patients taking antiplatelet therapy is less well understood. Although data are limited, a few small-scale studies ${ }^{23,24}$ suggest that hemorrhagic complications following thoracentesis in patients receiving clopidogrel are comparable to the general population. We found no compelling data regarding the safety of thoracentesis in the setting of direct oral anticoagulants, heparin, low-molecular weight heparin, or intravenous direct thrombin inhibitors. Current practice is to generally avoid thoracentesis while these therapeutic anticoagulants are used.

Invasive mechanical ventilation. Pleural effusion is common in patients in the intensive care unit, including those requiring mechanical ventilation. ${ }^{25}$ Thoracentesis in this population is clinically important: fluid analysis in 1 study was shown to aid the diagnosis in $45 \%$ of cases and changes in treatment in $33 \% .{ }^{26}$ However, clinicians may be reluctant to perform thoracentesis on patients who require mechanical ventilation, given the perception of a greater risk of pneumothorax from positive pressure ventilation.

Despite this concern, a 2011 meta-analysis including 19 studies and more than 1100 patients revealed rates of pneumothorax and hemothorax comparable to nonventilated patients. ${ }^{25}$ Furthermore, a 2015 prospective study that examined thoracentesis in 1377 mechanically ventilated patients revealed no difference in complication rates as well. ${ }^{20}$ Therefore, evidence suggests that performance of thoracentesis in mechanically ventilated patients is not contraindicated.

\section{Skin Disinfection and Antisepsis Precautions}

The 2010 BTS guidelines list empyema and wound infection as possible complications of thoracentesis. ${ }^{19}$ However, no 
data regarding incidence are provided. Additionally, an alcohol-based skin cleanser (such as 2\% chlorhexidine gluconate/70\% isopropyl alcohol), along with sterile gloves, field, and dressing are suggested as precautionary measures. ${ }^{19}$ In 1 single-center registry of 2489 thoracenteses performed using alcohol or iodine-based antiseptic and sterile drapes, no postprocedure infections were identified. ${ }^{27}$ Of note, we did not find other studies (including case reports) that reported either incidence or rate of infectious complications such as wound infection and empyema. In an era of modern skin antiseptics that have effectively reduced complications such as catheter-related bloodstream infection, ${ }^{28}$ the incidence of this event is thus likely to be low.

\section{INTRAPROCEDURAL CONSIDERATIONS Use of Bedside Ultrasound}

Portable US has particular advantages for evaluation of pleural effusion vs other imaging modalities. Compared with computerized tomography (CT), bedside US offers similar performance but is less costly, avoids both radiation exposure and need for patient transportation, and provides results instantaneously. ${ }^{29,30}$ Compared to chest $\mathrm{x}$-ray (CXR), US is more sensitive at detecting the presence, volume, and characteristics of pleural fluid ${ }^{30,31}$ and can be up to $100 \%$ sensitive for effusions greater than $100 \mathrm{~mL} .{ }^{29}$ Furthermore, whereas CXR typically requires $200 \mathrm{~mL}$ of fluid to be present for detection of an effusion, US can reliably detect as little as $20 \mathrm{~mL}$ of fluid. ${ }^{29}$ When US was used to confirm thoracentesis puncture sites in a study involving 30 physicians of varying experience and 67 consecutive patients, $15 \%$ of sites found by clinical exam were inaccurate (less than $10 \mathrm{~mm}$ fluid present), $10 \%$ were at high risk for organ puncture, and a suitable fluid pocket was found $54 \%$ of times when exam could not. ${ }^{4}$

A 2010 meta-analysis of 24 studies and 6605 thoracenteses estimated the overall rate of pneumothorax at $6 \%$; however, procedures performed with US guidance were associated with a $70 \%$ reduced risk of this event (odds ratio, $0.30 ; 95 \%$ confidence interval, $0.20-0.70) .{ }^{32}$ In a 2014 randomized control trial of 160 patients that compared thoracentesis with US guidance for site marking vs no US use, 10 pneumothoraces occurred in the control group vs 1 in the US group ( $12.5 \%$ vs $1.25 \%, P=0.009) .{ }^{33}$ Similarly, another retrospective review of 445 consecutive patients with malignant effusions revealed a pneumothorax rate of $0.97 \%$ using US in real time during needle insertion compared to $8.89 \%$ for unguided thoracenteses $(P<0.0001) .{ }^{34}$ Several other studies using US guidance for either site markup or in real time reported similar pneumothorax rates, ranging from $1.1 \%-4.8 \% .{ }^{35-37}$ However, it is unclear if real-time US specifically provides an additive effect vs site marking alone, as no studies directly comparing the 2 methods were found.

Benefits of US also include a higher rate of procedural success, with 1 study demonstrating a 99\% success rate when using US vs. $90 \%$ without $(P=0.030) .{ }^{33} \mathrm{~A}$ larger volume of fluid removed has been observed with US use as well, and methods have been described using fluid-pocket depth to guide puncture site localization and maximize drainage. ${ }^{38}$ Finally, US use for thoracentesis has been associated with lower costs and length of stay. ${ }^{39,40}$

\section{Intercostal Artery Localization}

Although rare (incidence, $0.18 \%-2 \%{ }^{20,21,39}$ ), the occurrence of hemothorax following thoracentesis is potentially catastrophic. This serious complication is often caused by laceration of the intercostal artery (ICA) or 1 of its branches during needle insertion..$^{41}$

While risk of injury is theoretically reduced by needle insertion superior to the rib, studies using cadaver dissection and 3D angiography show significant tortuosity of the ICA. ${ }^{6,41-43}$ The degree of tortuosity is increased within $6 \mathrm{~cm}$ of the midline, in more cephalad rib spaces, and in the elderly (older than 60 years). ${ }^{41-43}$ Furthermore, 1 cadaveric study also demonstrated the presence of arterial collaterals branching off the ICA at multiple intercostal spaces, ranging between $8 \mathrm{~cm}$ and $11 \mathrm{~cm}$ from the midline. ${ }^{41}$ This anatomic variability may explain why some have observed low complication and hemothorax rates with an extreme lateral approach. ${ }^{35}$ Bedside US with color flow Doppler imaging has been used to identify the ICA, with $88 \%$ sensitivity compared to CT imaging while adding little to exam time. ${ }^{44,45}$ Of note, a $37 \%$ drop in the rate of hemothorax was observed in 1 study with routine US guidance alone. ${ }^{39}$

\section{Pleural Pressure Monitoring and Large-Volume Thoracentesis}

While normal intrapleural pressures are approximately -5 to $-10 \mathrm{~cm} \mathrm{H}_{2} \mathrm{O},{ }^{46}$ the presence of a pleural effusion creates a complex interaction between fluid, compressed lung, and chest wall that can increase these pressures ${ }^{47}$ During drainage of an effusion, pleural pressures may rapidly drop, provoking re-expansion pulmonary edema (REPE). While rare $(0-1 \%)$, clinically-diagnosed REPE is a serious complication that can lead to rapid respiratory failure and death..$^{20,48}$ REPE is postulated to be caused by increased capillary permeability resulting from inflammation, driven by rapid re-inflation of the lung when exposed to highly negative intrapleural pressures. ${ }^{47,49}$

Measurement of intrapleural pressure using a water manometer during thoracentesis may minimize REPE by terminating fluid drainage when intrapleural pressure begins to drop rapidly. ${ }^{50,51}$ A cutoff of $-20 \mathrm{~cm} \mathrm{H}_{2} \mathrm{O}$ has been cited repeatedly as safe since being suggested by Light in 1980, but this is based on animal models. ${ }^{50,52}$ In 1 prospective study of 185 thoracenteses in which manometry was performed, $15 \%$ of patients had intrapleural pressure drop to less than -20 $\mathrm{cm} \mathrm{H}_{2} \mathrm{O}$ (at which point the procedure was terminated) but suffered no REPE. ${ }^{50}$

Manometry is valuable in the identification of an unexpandable or trapped lung when pleural pressures drop rapidly with only minimal fluid volume removal. ${ }^{47,53}$ Other findings

Continued on page 273 


\section{TABLE. Summary of Studies in Review, Organized by Topic}

\begin{tabular}{|c|c|c|c|c|}
\hline Topic & Author (Year) & Study Design & Participants (n) & Study Description or Intervention \\
\hline \multirow[t]{4}{*}{$\begin{array}{l}\text { Physician } \\
\text { training }\end{array}$} & $\begin{array}{l}\text { Grover S, et al } \\
(2009)^{8}\end{array}$ & Cohort survey & $188 \mathrm{IM}$ residents & $\begin{array}{l}\text { Assess resident knowledge of } 3 \text { core medical } \\
\text { procedures; } 32 \text {-item multiple choice test developed } \\
\text { and given to students, residents, and clinicians }\end{array}$ \\
\hline & $\begin{array}{l}\text { Promes S, et al } \\
(2009)^{9}\end{array}$ & Cohort survey & $\begin{array}{l}2561^{\text {st }} \text { y } \mathrm{IM} \\
\text { residents at } 3 \\
\text { training sites }\end{array}$ & $\begin{array}{l}\text { Self-reported survey to evaluate attitudes, } \\
\text { competency, and exposure to common medical } \\
\text { procedures in medical school }\end{array}$ \\
\hline & $\begin{array}{l}\text { Huang G, et al } \\
(2006)^{10}\end{array}$ & $\begin{array}{l}\text { Prospective } \\
\text { cohort }\end{array}$ & $106 \mathrm{IM}$ residents & $\begin{array}{l}\text { Residents logged procedures performed, answering } \\
\text { questions evaluating their comfort with } 9 \text { aspects of } \\
4 \text { medical procedures }\end{array}$ \\
\hline & $\begin{array}{l}\text { Lagan J, et al } \\
(2015)^{11}\end{array}$ & Online survey & $\begin{array}{l}156 \text { medical } \\
\text { trainees }\end{array}$ & $\begin{array}{l}\text { Online survey given to trainees regarding attitudes } \\
\text { and experience related to medicine procedures }\end{array}$ \\
\hline
\end{tabular}

\begin{tabular}{|c|c|c|c|}
\hline $\begin{array}{l}\text { Wayne D, et al } \\
(2008)^{12}\end{array}$ & $\begin{array}{l}\text { Pretest-posttest } \\
\text { design with no } \\
\text { control }\end{array}$ & $\begin{array}{l}403^{\text {rd }} \text { y IM } \\
\text { residents }\end{array}$ & $\begin{array}{l}\text { Baseline knowledge and skills assessment followed } \\
\text { by video instruction and deliberate practice on } \\
\text { thoracentesis simulator until competence attained }\end{array}$ \\
\hline
\end{tabular}

\begin{tabular}{llll}
\hline $\begin{array}{l}\text { Lenchus J } \\
(2010)^{13}\end{array}$ & $\begin{array}{l}\text { Case cohort } \\
\text { before and after }\end{array}$ & $\begin{array}{l}56 \text { residents and } 4 \\
\text { medical students }\end{array}$ & $\begin{array}{l}\text { Procedural instruction curriculum (including } \\
\text { thoracentesis) and pilot developed consisting of } \\
\text { instruction with videos, simulation, and deliberate } \\
\text { practice; knowledge, and skills assessed before } \\
\text { and after }\end{array}$ \\
\hline $\begin{array}{llll}\text { Lenchus J, et al } \\
(2011)^{14}\end{array}$ & $\begin{array}{l}\text { Case cohort } \\
\text { before and after }\end{array}$ & $85 \mathrm{IM}$ residents & $\begin{array}{l}\text { Residents completed } 4 \text { wk multimodal procedure } \\
\text { course including simulation; assessed with a } \\
\text { knowledge and skills test before and after }\end{array}$ \\
\hline $\begin{array}{llll}\text { Duncan D, et al } \\
(2009)^{7}\end{array}$ & $\begin{array}{l}\text { Prospective } \\
\text { cohort }\end{array}$ & 244 procedures & $\begin{array}{l}\text { Institution of a training system to reduce } \\
\text { pneumothorax rate including focused group of } \\
\text { operators, ultrasound, and standardization of } \\
\text { methods and equipment }\end{array}$ \\
\hline $\begin{array}{l}\text { Jiang G, et al } \\
(2011)^{15}\end{array}$ & $\begin{array}{l}\text { Case cohort } \\
\text { before and after }\end{array}$ & $\begin{array}{l}52 \text { medical } \\
\text { students }\end{array}$ & $\begin{array}{l}\text { Students performed repeated trials on a thoracentesis } \\
\text { simulator, and performance was recorded }\end{array}$ \\
\hline
\end{tabular}

\begin{tabular}{|c|c|c|c|}
\hline $\begin{array}{l}\text { Berg D, et al } \\
(2013)^{16}\end{array}$ & NA & $\begin{array}{l}8 \text { physician } \\
\text { experts }\end{array}$ & $\begin{array}{l}\text { Checklist developed to aid in the standardization of } \\
\text { thoracentesis training and competence evaluation }\end{array}$ \\
\hline
\end{tabular}

\begin{tabular}{|c|c|c|c|c|}
\hline & $\begin{array}{l}\text { Salamonsen M, } \\
\text { et al }(2013)^{17}\end{array}$ & NA & 22 trainees & $\begin{array}{l}\text { 11-domain, 100-point scoring tool developed to } \\
\text { gauge thoracic US competence; used to score } \\
\text { participant performance on simulator }\end{array}$ \\
\hline $\begin{array}{l}\text { Coagulopathies } \\
\text { and } \\
\text { anticoagulation }\end{array}$ & $\begin{array}{l}\text { Havelock T, et al } \\
(2010)^{19}\end{array}$ & $\begin{array}{l}\text { Consensus } \\
\text { guidelines }\end{array}$ & NA & $\begin{array}{l}\text { Literature review and expert opinion regarding the } \\
\text { preparation, technique, and complications related to } \\
\text { bedside thoracentesis }\end{array}$ \\
\hline
\end{tabular}

\begin{tabular}{llll}
\hline $\begin{array}{l}\text { Patel I, et al } \\
(2012)^{5}\end{array}$ & $\begin{array}{l}\text { Consensus NA } \\
\text { guidelines }\end{array}$ & $\begin{array}{l}\text { Literature review and expert opinion used to } \\
\text { determine best practices related to the hematologic } \\
\text { management of patients undergoing percutaneous } \\
\text { interventions }\end{array}$ \\
\hline $\begin{array}{lll}\text { Ault M, et al } \\
2015)^{20}\end{array}$ & $\begin{array}{l}\text { Prospective } \\
\text { cohort }\end{array}$ & $\begin{array}{l}9320 \\
\text { thoracenteses }\end{array}$ & $\begin{array}{l}\text { To evaluate specific demographic and clinical factors } \\
\text { that have been associated with complications of } \\
\text { thoracentesis }\end{array}$
\end{tabular}

\begin{tabular}{llll}
\hline $\begin{array}{l}\text { Puchalski J } \\
(2014)^{21}\end{array}$ & Literature review & $\begin{array}{l}8 \text { studies, } 2600 \\
\text { procedures }\end{array}$ & $\begin{array}{l}\text { Review of the literature regarding the risk of bleeding } \\
\text { complications after thoracentesis in patients } \\
\text { with baseline coagulopathy and the practice of } \\
\text { prophylactic reversal }\end{array}$ \\
\hline $\begin{array}{llll}\text { Hibbert R, et al } \\
(2013)^{22}\end{array}$ & $\begin{array}{l}\text { Retrospective } \\
\text { chart review }\end{array}$ & 1009 procedures & $\begin{array}{l}\text { Chart review of US-guided thoracenteses done } \\
\text { with INR }>1.6 \text { or platelets }<50,000 / \mu L ; \text { patients } \\
\text { separated by whether or not coagulopathy corrected } \\
\text { prior with blood products }\end{array}$ \\
\hline $\begin{array}{l}\text { Zalt M, et al } \\
(2012)^{23}\end{array}$ & $\begin{array}{l}\text { Prospective } \\
\text { cohort }\end{array}$ & $\begin{array}{l}30 \text { patients, } 45 \\
\text { thoracenteses }\end{array}$ & $\begin{array}{l}\text { US-guided thoracentesis performed in patients on } \\
\text { clopidogrel with symptomatic effusion, assessed for } \\
\text { bleeding complications postprocedure }\end{array}$
\end{tabular}

$\begin{array}{lll}\text { Mahmood K, } & \text { Prospective } & 75 \text { patients } \\ \text { et al }(2014)^{24} & \begin{array}{l}\text { cohort with } \\ \text { control group }\end{array}\end{array}$

Results and Authors' Conclusions

The instrument was reliable ( $\alpha=0.79$ ); resident median score was

$53 \%$; overall knowledge of procedures was poor

New medical interns report having the least experience and

confidence with thoracentesis of all procedures

Many residents are uncomfortable performing bedside procedures, especially when unsupervised (37\%); thoracentesis associated with less comfort (OR, 0.40; $\mathrm{Cl}, 0.20-0.80)$

Majority of trainees felt procedures were important and wanted more exposure; trainees did not feel competent in independent US use thoracentesis confidence positively correlated with exposure $(P<$ 0.003).

Simulation with deliberate practice led to a $71 \%$ improvement in clinical skills exam, with $100 \%$ reaching the mastery standard; amount of practice time required was a negative predictor of posttest performance

Standardized course resulted in significantly increased knowledge scores for all procedures $(P<0.001)$, along with increased technical skills rated on first patient performance $(P<0.001)$

All participants demonstrated an improvement in medical knowledge and technical skills $(P<0.05)$; a blended, standardized procedure curriculum has potential to address shortcomings of traditional training

Institution of improvement program with simulation and US reduced rates of pneumothorax from $8.6 \%$ to $1.1 \%(P=0.0034)$; effect sustained for $2 y$

Performance score, time, and confidence were maximized after tria number $4(P<0.05)$; effect persisted at $6 \mathrm{mo}$ on retest and $12 \mathrm{mo}$ on first live patient

Developed a 23-point checklist with a high level of agreement between experts $(\alpha=0.94)$; requires implementation for validation in simulation and clinical environment

The tool reliably predicted experience level (novice, intermediate, expert) regarding thoracic US use and effusion markup $(P<0.0001)$; can be used to document adequacy of US training

Thoracentesis can be safely performed in most patients with INR $<1.5$ and platelets $>50,000 / \mathrm{LL}$, US guidance is recommended; routine postprocedure chest $\mathrm{X}$-ray (CXR) not indicated unless concern for complication

Thoracentesis is a low-risk bleeding procedure; recommend performance if INR $<2.0$ and platelets $>50,000 / \mu \mathrm{L}$; benefit of prophylactic transfusion unclear and risk/benefit should be weighed by physician

Low rate of complications with experienced operator; no increase in risk with moderate coagulopathy $(P=0.97$ INR category, $P=0.55$ platelet category); risk factors for complications included $>1$ needle pass $(P=0.002)$ and $>1.5 \mathrm{~L}$ fluid removed $(P=0.0001)$

Thoracentesis appears to be safe to perform despite significant coagulation abnormalities (INR $<3$, platelets $>25,000 / \mu \mathrm{L}$ ); prophylactic reversal of coagulation abnormalities not beneficial

Despite the presence of coagulopathy, the risk of hemorrhagic complication is very low $(0.40 \% ; \mathrm{Cl} 0.15 \%-1.02 \%)$; prophylactic transfusion of blood products did not alter this risk

No clinically significant bleeding complications observed; unnecessary to hold clopidogrel before US-guided thoracentesis for symptomatic effusion as bleeding risk is low; larger studies required to confirm results

25 patients underwent US-guided percutaneous pleural intervention without cessation of clopidogrel; bleeding rates compared with control group
1 patient on clopidogrel developed a hemothorax requiring transfusion (overall rate, $4 \%$ ); clinically significant bleeding risk is low and comparable to control group $(P=0.15)$ 
TABLE. Summary of Studies in Review, Organized by Topic (continued)

\begin{tabular}{|c|c|c|c|c|}
\hline Topic & Author (Year) & Study Design & Participants (n) & Study Description or Intervention \\
\hline \multirow[t]{2}{*}{$\begin{array}{l}\text { Invasive } \\
\text { mechanical } \\
\text { ventilation }\end{array}$} & $\begin{array}{l}\text { Goligher E, et al } \\
(2011)^{25}\end{array}$ & $\begin{array}{l}\text { Systematic } \\
\text { review and meta- } \\
\text { analysis }\end{array}$ & $\begin{array}{l}19 \text { studies, } 1124 \\
\text { thoracenteses }\end{array}$ & $\begin{array}{l}\text { Review of studies relevant to the utility and safety of } \\
\text { draining pleural effusions in patients on mechanical } \\
\text { ventilation }\end{array}$ \\
\hline & $\begin{array}{l}\text { Fartoukh M, } \\
\text { et al }(2002)^{26}\end{array}$ & $\begin{array}{l}\text { Prospective } \\
\text { cohort }\end{array}$ & $\begin{array}{l}113 \text { patients, } 68 \\
\text { on mechanical } \\
\text { ventilation }\end{array}$ & $\begin{array}{l}\text { MICU patients with effusion underwent thoracentesis; } \\
\text { clinicians queried on both pre- and post-tap } \\
\text { diagnosis }\end{array}$ \\
\hline $\begin{array}{l}\text { Skin disinfection } \\
\text { and antisepsis } \\
\text { precautions }\end{array}$ & $\begin{array}{l}\text { Cervini P, et al } \\
(2010)^{27}\end{array}$ & $\begin{array}{l}\text { Retrospective } \\
\text { chart review }\end{array}$ & $\begin{array}{l}2489 \\
\text { thoracenteses }\end{array}$ & $\begin{array}{l}\text { Chart review of patients who underwent US-guided } \\
\text { thoracentesis to evaluate for infectious complications } \\
\text { and determine infection rate }\end{array}$ \\
\hline $\begin{array}{l}\text { Use of bedside } \\
\text { ultrasound }\end{array}$ & $\begin{array}{l}\text { Soni N, et al } \\
(2015)^{29}\end{array}$ & Literature review & NA & $\begin{array}{l}\text { Review of the literature related to the use of point-of- } \\
\text { care US to evaluate and mange pleural effusions }\end{array}$ \\
\hline
\end{tabular}

Results and Authors' Conclusions

Rates of pneumothorax (3.4\%; Cl, 1.7-6.5\%) and hemothorax (1.6\%;

$\mathrm{Cl}, 0.8-3.3 \%$ ) were low; drainage of pleural effusions in mechanically ventilated patients is safe and appears to improve oxygenation

$8.4 \%$ of MICU patients had an effusion; thoracentesis aided treatment in $56 \%$ of cases and altered the final diagnosis in $45 \%$ of cases; pneumothorax noted in 6 patients $(7 \%)$

US-guided thoracentesis confers an extremely low risk of infectious complication when aseptic technique is used; no infections were observed

Regarding pleural effusion characterization US performs similarly to $\mathrm{CT}$ and is more sensitive than CXR; US guidance reduces thoracentesis complications and increases success rates

Feller-Kopman D Literature review NA $(2006)^{30}$

Review of the basic techniques of bedside US related to evaluation of pleural disease and performance of thoracentesis

US guidance improves patient outcomes by reducing the risk of complication, and is especially helpful in the setting of small effusions and mechanical ventilation

Shojaee $S$ and Literature review NA Argento A

$(2014)^{31}$

Literature reviewed pertaining to basic US physiology,
common thoracic exam findings, and utility related to

Bedside US during thoracentesis is recommended because common thoracic exam findings, and utility related to it provides immediate results, improved site selection, fewer pleural access

Diacon A, et al Prospective 67 consecutive To assess the value of thoracentesis puncture sites $(2003)^{4} \quad$ comparative patients identified by clinical examination alone; clinicianproposed locations were evaluated for accuracy against thoracic US

US found that $15 \%$ of clinician exam-proposed puncture sites to be inaccurate ( $<10 \mathrm{~mm}$ fluid depth) with $10 \%$ of sites overlying solid organs; US able to identify accurate pocket in $54 \%$ of cases where exam could not; US increases procedure yield and potentially reduces complications

\begin{tabular}{|c|c|c|c|}
\hline $\begin{array}{l}\text { Gordon C, et al } \\
(2010)^{32}\end{array}$ & $\begin{array}{l}\text { Systematic } \\
\text { review and meta- } \\
\text { analysis }\end{array}$ & $\begin{array}{l}24 \text { studies, } 6605 \\
\text { thoracenteses }\end{array}$ & $\begin{array}{l}\text { Literature reviewed to determine the baseline rate of } \\
\text { pneumothorax related to thoracentesis and identify } \\
\text { influencing factors }\end{array}$ \\
\hline
\end{tabular}

Overall calculated risk of pneumothorax was $6 \%(95 \% \mathrm{Cl}, 4.6 \%$ $7.8 \%)$; US guidance associated with lower risk (OR, 0.3; $\mathrm{Cl}, 0.2-0.7)$; factors increasing this risk were therapeutic indication $(\mathrm{OR}, 2.6 ; \mathrm{Cl}$, 1.8-3.8) and periprocedural symptoms (OR, 26.6; $\mathrm{Cl}, 2.7-262.5)$

$\begin{array}{lll}\text { Perazzo A, et al } & \begin{array}{l}\text { Randomized } \\ (2014)^{33}\end{array} & \text { control trial }\end{array}$

Patients randomized to thoracentesis with or without US use prior to identifying fluid pocket; Use of US prior to thoracentesis resulted in a significantly lower rate of pneumothorax $(1.25 \%$ vs $12.5 \%, P=0.009)$, higher procedure measured rate of procedure success, fluid yield, and success $(99 \%$ vs $90 \%, P=0.03)$ and higher fluid yield $(P>0.014)$ pneumothorax

\begin{tabular}{llll}
\hline $\begin{array}{l}\text { Cavanna L, et al } \\
(2014)^{34}\end{array}$ & $\begin{array}{l}\text { Retrospective } \\
\text { chart review }\end{array}$ & $\begin{array}{l}445 \text { patients with } \\
\text { malignant pleural } \\
\text { effusions }\end{array}$ & $\begin{array}{l}\text { Chart review of patients status post-thoracentesis } \\
\text { with or without real-time US guidance; procedure } \\
\text { success, yield, and complication rates compared }\end{array}$ \\
\hline $\begin{array}{llll}\text { Soldati G, et al } \\
(2013)^{35}\end{array}$ & $\begin{array}{l}\text { Prospective } \\
\text { cohort }\end{array}$ & $\begin{array}{l}106 \text { patients, } \\
131 \text { procedures }\end{array}$ & $\begin{array}{l}\text { Evaluate efficacy and safety of thoracentesis or pigtail } \\
\text { catheter placement in the supine or lateral recumbent } \\
\text { position under real-time US guidance }\end{array}$
\end{tabular}

US guidance used in 310 (69\%) thoracenteses; use of real-time US guidance during thoracentesis for malignant effusions resulted in drastically lower pneumothorax rates $(0.89 \%$ vs $8.89 \%, P=0.0001)$ position under real-time US guidance

$97 \%$ of all procedures successful; pneumothorax rate was $1.4 \%$ with no bleeding complications observed; pleural procedures in the supine ore secumbent positions are somfortable, and conducive to real-time US guidance

\begin{tabular}{|c|c|c|c|c|}
\hline $\begin{array}{l}\text { Pihlajamaa K, } \\
\text { et al }(2004)^{36}\end{array}$ & $\begin{array}{l}\text { Retrospective } \\
\text { chart review }\end{array}$ & $\begin{array}{l}212 \text { patients, } 264 \\
\text { thoracenteses }\end{array}$ & $\begin{array}{l}\text { Chart review performed to determine the incidence } \\
\text { of pneumothorax and contributing variables after } \\
\text { US-guided thoracentesis }\end{array}$ & $\begin{array}{l}\text { Post-thoracentesis pneumothorax rates were low }(4.2 \%) \text { with no } \\
\text { increase in risk in mechanical ventilation or based on operator } \\
\text { experience; recommend against routine CXR postprocedure }\end{array}$ \\
\hline $\begin{array}{l}\text { Barnes T, et al } \\
(2005)^{37}\end{array}$ & $\begin{array}{l}\text { Retrospective } \\
\text { chart review }\end{array}$ & 450 thoracenteses & $\begin{array}{l}\text { Charts reviewed of all thoracenteses performed over } \\
1 \text {-year period, assessing for use of US and relation to } \\
\text { pneumothorax rates }\end{array}$ & $\begin{array}{l}\text { Use of US prior to thoracentesis resulted in a significantly lower rate } \\
\text { of pneumothorax ( } 4.9 \% \text { vs } 10.3 \%, P<0.05) \text {; recommend US use be } \\
\text { considered in all patients }\end{array}$ \\
\hline $\begin{array}{l}\text { Hooper C, et al } \\
(2015)^{3}\end{array}$ & $\begin{array}{l}\text { Retrospective } \\
\text { review }\end{array}$ & $\begin{array}{l}1252 \\
\text { thoracenteses }\end{array}$ & $\begin{array}{l}\text { British Thoracic Society pleural procedures audit } \\
\text { of } 90 \text { hospitals over a } 2 \text {-mo period outlining } \\
\text { complication rates, consent rates, and use of bedside } \\
\text { US }\end{array}$ & $\begin{array}{l}\text { Rates of pneumothorax (1.3\%) and hemothorax (1.1\%) are low; } \\
\text { use of US guidance is rising since } 2010 \text { ( } 69 \% \text { vs } 52 \%) ; 50 \% \text { of } \\
\text { thoracenteses are still performed at bedside }\end{array}$ \\
\hline $\begin{array}{l}\text { Zanforlin A, et al } \\
(2013)^{38}\end{array}$ & $\begin{array}{l}\text { Prospective } \\
\text { cohort }\end{array}$ & 45 thoracenteses & $\begin{array}{l}\text { Assessment of safety and efficacy of thoracentesis } \\
\text { performed over the area of effusion with maximum } \\
\text { depth between lung and diaphragm as identified on } \\
\text { bedside US ("V-point") }\end{array}$ & $\begin{array}{l}\text { The "V point" is an easy-to-identify US landmark that provides } \\
\text { a safe area for needle puncture; no pneumothoraces observed; } \\
\text { measurement of maximum pocket depth provides a rough estimation } \\
\text { of effusion volume }\end{array}$ \\
\hline $\begin{array}{l}\text { Patel P, et al } \\
(2012)^{39}\end{array}$ & $\begin{array}{l}\text { Retrospective } \\
\text { chart review }\end{array}$ & $\begin{array}{l}19,339 \\
\text { thoracenteses }\end{array}$ & $\begin{array}{l}\text { Premier hospital database queried for thoracenteses } \\
\text { performed over 1-y period; cost analysis performed } \\
\text { to determine if use of US led to a change in } \\
\text { outcomes and cost }\end{array}$ & $\begin{array}{l}\text { US guidance was used in } 46 \% \text { of thoracenteses; associated with a } \\
\text { decrease in pneumothorax of } 16.3 \%(0 \mathrm{R}, 0.837 ; \mathrm{Cl}, 0.73-0.96, P= \\
0.014) \text { and hemothorax by } 38.7 \%(0 \mathrm{R}, 0.613 ; \mathrm{Cl}, 0.36-1.04 ; P= \\
0.071) \text {; US use was associated with a lower cost of hospitalization }(P \\
<0.0001) \text { and shorter length of stay }(P<0.0001)\end{array}$ \\
\hline $\begin{array}{l}\text { Mercaldi C and } \\
\text { Lanes S } \\
(2013)^{40}\end{array}$ & $\begin{array}{l}\text { Retrospective } \\
\text { chart review }\end{array}$ & $\begin{array}{l}61,261 \\
\text { thoracenteses }\end{array}$ & $\begin{array}{l}\text { Claims data reviewed over 2-y period on } \\
\text { thoracenteses with analysis of US use, } \\
\text { pneumothorax, length of stay, and hospitalization cost }\end{array}$ & $\begin{array}{l}\text { Use of US during thoracentesis resulted in a reduction in } \\
\text { pneumothorax by } 19 \%(0 \mathrm{R}, 0.81 ; \mathrm{Cl}, 0.74-0.90) ; \text { pneumothorax } \\
\text { occurrence found to increase hospital cost by } \$ 2801(P<0.001) \\
\text { and length of stay by } 1.5 \text { days }(P>0.001)\end{array}$ \\
\hline $\begin{array}{l}\text { Celik B, et al } \\
(2009)^{2}\end{array}$ & $\begin{array}{l}\text { Retrospective } \\
\text { chart review }\end{array}$ & $\begin{array}{l}12,010 \text { invasive } \\
\text { procedures }\end{array}$ & $\begin{array}{l}\text { Records of patients treated for iatrogenic } \\
\text { pneumothorax reviewed to determine causal } \\
\text { procedure, location, service, treatment required, and } \\
\text { consequences }\end{array}$ & $\begin{array}{l}164 \text { cases of iatrogenic pneumothorax were identified }(1.36 \%) \text {; } \\
\text { highest risk procedures included central venous catheter insertion } \\
\text { ( } 43.8 \% \text { of cases) and thoracentesis ( } 20.1 \% \text { of cases); } 56.7 \% \text { of } \\
\text { procedures causing pneumothorax were performed under emergency } \\
\text { conditions }\end{array}$ \\
\hline
\end{tabular}

Continued on page 272 


\section{TABLE. Summary of Studies in Review, Organized by Topic (continued)}

\begin{tabular}{|c|c|c|c|c|c|}
\hline Topic & Author (Year) & Study Design & Participants (n) & Study Description or Intervention & Results and Authors' Conclusions \\
\hline $\begin{array}{l}\text { Intercostal artery } \\
\text { localization }\end{array}$ & $\begin{array}{l}\text { Shurtleff E and } \\
\text { Olinger A } \\
(2012)^{41}\end{array}$ & $\begin{array}{l}\text { Observational } \\
\text { cohort }\end{array}$ & 29 cadavers & $\begin{array}{l}\text { Identify the course and tortuosity of the posterior } \\
\text { intercostal coronary artery (ICA) and its collaterals in } \\
\text { elderly cadavers using dissection }\end{array}$ & $\begin{array}{l}\text { The ICA is unshielded and most tortuous in its course near the } \\
\text { posterior midline, also demonstrating collaterals within the first } \\
120 \mathrm{~mm} \text {; age }>60 \text { was associated with higher rates of tortuosity; } \\
\text { recommend tall pleural procedures be performed } \geq 120 \mathrm{~mm} \text { from } \\
\text { midline }\end{array}$ \\
\hline
\end{tabular}

\begin{tabular}{llll}
\hline $\begin{array}{l}\text { Helm E, et al } \\
(2013)^{42}\end{array}$ & $\begin{array}{l}\text { Retrospective } \\
\text { review }\end{array}$ & $\begin{array}{l}47 \text { patients, } \\
298 \text { arteries }\end{array}$ & $\begin{array}{l}\text { Thoracic CT angiograms reformatted and analyzed } \\
\text { to describe the course and variability in the ICAs and } \\
\text { the factors that may influence them }\end{array}$
\end{tabular}

\begin{tabular}{llll}
\hline $\begin{array}{l}\text { Yoneyama } \mathrm{H}, \\
\text { et al }(2010)^{43}\end{array}$ & $\begin{array}{l}\text { Observational } \\
\text { cohort }\end{array}$ & 33 patients & $\begin{array}{l}\text { 3D CT angiography was performed in elderly patients } \\
\text { to identify the ICA with calculation of the "percent } \\
\text { safe space" to quantify vulnerability of laceration } \\
\text { during thoracentesis }\end{array}$ \\
\hline $\begin{array}{lll}\text { Salamonsen M, } \\
\text { et al (2012) }\end{array}$ & $\begin{array}{l}\text { Prospective } \\
\text { cohort }\end{array}$ & 22 patients & $\begin{array}{l}\text { Describe a method to visualize the ICA prior to } \\
\text { thoracentesis using US, and calculate its location } \\
\text { relative to the overlying rib to identify a "vulnerable" } \\
\text { vessel }\end{array}$ \\
\hline $\begin{array}{l}\text { Salamonsen M, } \\
\text { et al (2013) }\end{array}$ & $\begin{array}{l}\text { Prospective } \\
\text { cohort }\end{array}$ & 50 patients & $\begin{array}{l}\text { Physicians evaluate the reliability of bedside US } \\
\text { to identify the ICA in patients prior to planned CT } \\
\text { thoracic angiography as gold standard }\end{array}$ \\
\end{tabular}

\begin{tabular}{lll}
\hline Wraight W, et al & Observational & 38 cadavers \\
$(2005)^{6}$ & cohort & 62 rib block
\end{tabular}

Rib blocks dissected to identify the neurovascular bundle and measure its relation to the inferior rib border and attempt to describe a "safe zone" for drain insertion

\begin{tabular}{|c|c|c|c|c|}
\hline \multirow[t]{6}{*}{$\begin{array}{l}\text { Pleural pressure } \\
\text { monitoring and } \\
\text { large-volume } \\
\text { thoracentesis }\end{array}$} & $\begin{array}{l}\text { Huggins J and } \\
\text { Doelken P } \\
(2006)^{47}\end{array}$ & Literature review & NA & $\begin{array}{l}\text { This review discusses pleural mechanics and } \\
\text { pleural manometry including its role in re-expansion } \\
\text { pulmonary edema (REPE) and diagnosing of a } \\
\text { nonexpandable lung }\end{array}$ \\
\hline & $\begin{array}{l}\text { Echevarria C, } \\
\text { et al }(2008)^{48}\end{array}$ & Systematic review & 13 studies & $\begin{array}{l}\text { Literature review performed to determine the } \\
\text { prevalence of REPE after thoracentesis and } \\
\text { associated risk factors }\end{array}$ \\
\hline & $\begin{array}{l}\text { Sue R, et al } \\
(2004)^{49}\end{array}$ & Retrospective & $\begin{array}{l}7 \text { patients on } \\
\text { mechanical } \\
\text { ventilation }\end{array}$ & $\begin{array}{l}\text { To investigate if clinical REPE is due to increased } \\
\text { permeability of the alveolar capillary barrier through } \\
\text { analysis of pulmonary edema fluid and plasma }\end{array}$ \\
\hline & $\begin{array}{l}\text { Feller-Kopman D, } \\
\text { et al }(2007)^{50}\end{array}$ & $\begin{array}{l}\text { Prospective } \\
\text { cohort }\end{array}$ & 185 thoracenteses & $\begin{array}{l}\text { Patients undergoing thoracentesis with }>1 \mathrm{~L} \text { remove } \\
\text { had volume drained, pleural pressure, elastance, } \\
\text { and presence of symptoms recorded; parameters } \\
\text { compared with those who developed REPE }\end{array}$ \\
\hline & $\begin{array}{l}\text { Villena V, et al } \\
(2000)^{51}\end{array}$ & $\begin{array}{l}\text { Prospective } \\
\text { cohort }\end{array}$ & 61 patients & $\begin{array}{l}\text { During therapeutic thoracentesis, pleural pressures } \\
\text { were measured to determine if they could predict } \\
\text { the amount of fluid that could be safely removed or } \\
\text { effusion etiology }\end{array}$ \\
\hline & $\begin{array}{l}\text { Doelken P, et al } \\
(2004)^{52}\end{array}$ & $\begin{array}{l}\text { Prospective } \\
\text { cohort }\end{array}$ & 40 patients & $\begin{array}{l}\text { To compare the agreement between an electronic } \\
\text { transducer and water manometer in measuring } \\
\text { pleural pressures during thoracentesis }\end{array}$ \\
\hline
\end{tabular}

\begin{tabular}{|c|c|c|c|c|}
\hline & & & & $0.97 ; P<0.001)$ \\
\hline $\begin{array}{l}\text { Feller-Kopman D } \\
(2007)^{53}\end{array}$ & Literature review & NA & $\begin{array}{l}\text { This review summarizes the relevant data for the } \\
\text { use of US and manometry, and their use during } \\
\text { therapeutic thoracentesis }\end{array}$ & $\begin{array}{l}\text { The data regarding pleural US are sound enough to suggest its use } \\
\text { should become standard of care; further research is required to } \\
\text { define the role of formal manometry }\end{array}$ \\
\hline $\begin{array}{l}\text { Boshuizen R, } \\
\text { et al }(2013)^{54}\end{array}$ & $\begin{array}{l}\text { Prospective } \\
\text { cohort }\end{array}$ & $\begin{array}{l}30 \text { patients, } 34 \\
\text { procedures }\end{array}$ & $\begin{array}{l}\text { Manometry used to explore the relationship between } \\
\text { pleural pressure and a nonexpanded lung in patients } \\
\text { with malignant effusions; compared with imaging to } \\
\text { check lung expansion }\end{array}$ & $\begin{array}{l}4 \text { patients were identified as having a nonexpanding lung; total drop } \\
\text { in pleural pressure }(P=0.009) \text {, difference in pleural pressure with } \\
\text { respiration }(P=0.007) \text {, and pleural elastance }(P=0.002) \text { were all } \\
\text { significantly associated with a nonexpanding lung }\end{array}$ \\
\hline $\begin{array}{l}\text { Pannu J, et al } \\
(2014)^{55}\end{array}$ & $\begin{array}{l}\text { Retrospective } \\
\text { chart review }\end{array}$ & 214 patients & $\begin{array}{l}\text { Chart review of thoracenteses performed with and } \\
\text { without manometry to assess for a correlation } \\
\text { between intrapleural pressure and patient discomfort }\end{array}$ & $\begin{array}{l}\text { The use of manometry did not reliably predict the change in chest } \\
\text { pain }(P=0.12) \text { or dyspnea }(P=0.24) \text { during thoracentesis; similar } \\
\text { results found in large-volume thoracentesis group }\end{array}$ \\
\hline $\begin{array}{l}\text { Feller-Kopman D, } \\
\text { et al }(2006)^{56}\end{array}$ & $\begin{array}{l}\text { Prospective } \\
\text { cohort }\end{array}$ & 169 patients & $\begin{array}{l}\text { Serial manometry performed during therapeutic } \\
\text { thoracentesis to explore the correlation between } \\
\text { intrapleural pressure changes and symptom onset }\end{array}$ & $\begin{array}{l}\text { Symptoms developed in } 17 \% \text { of patients; chest discomfort was } \\
\text { significantly associated with large drops in pleural pressure }(P= \\
0.001) \text {, but opening pressure and total volume removed were not }\end{array}$ \\
\hline $\begin{array}{l}\text { Abunasser J. } \\
\text { and Brown R } \\
(2010)^{57}\end{array}$ & $\begin{array}{l}\text { Retrospective } \\
\text { chart review }\end{array}$ & $\begin{array}{l}237 \text { patients, } 300 \\
\text { thoracenteses }\end{array}$ & $\begin{array}{l}\text { Charts reviewed of thoracenteses performed to } \\
\text { assess the risk of large-volume drainage }(>1 \mathrm{~L}) \\
\text { without manometry }\end{array}$ & $\begin{array}{l}137 \text { thoracenteses performed were large volume; no statistically } \\
\text { significant difference in the risk of pneumothorax, hypotension, or } \\
\text { bleeding }\end{array}$ \\
\hline
\end{tabular}

Continued on page 273 


\begin{tabular}{|c|c|c|c|c|c|}
\hline \multirow[t]{4}{*}{ Topic } & Author (Year) & Study Design & Participants (n) & Study Description or Intervention & Results and Authors' Conclusions \\
\hline & $\begin{array}{l}\text { Mynarek G, et al } \\
(2004)^{58}\end{array}$ & $\begin{array}{l}\text { Retrospective } \\
\text { chart review }\end{array}$ & $\begin{array}{l}711 \text { procedures in } \\
371 \text { patients }\end{array}$ & $\begin{array}{l}\text { Chart review performed of patients who underwent } \\
\text { US-guided thoracentesis to assess type and } \\
\text { frequency of complications and associated risk } \\
\text { factors }\end{array}$ & $\begin{array}{l}\text { US-guided thoracentesis is a safe procedure with a } 2.8 \% \text { rate of } \\
\text { pneumothorax; no association with the amount of fluid removed ( } P \\
=0.096) \text {; authors recommend against postprocedure CXR in the } \\
\text { absence of symptoms }\end{array}$ \\
\hline & $\begin{array}{l}\text { Josephson T, } \\
\text { et al }(2009)^{59}\end{array}$ & $\begin{array}{l}\text { Prospective } \\
\text { cohort }\end{array}$ & $\begin{array}{l}471 \text { patients, } 735 \\
\text { thoracenteses }\end{array}$ & $\begin{array}{l}\text { US-guided therapeutic thoracenteses performed and } \\
\text { effusions drained with no upper limit and without } \\
\text { manometry; stratified by amount of fluid removed } \\
\text { and pneumothorax rates analyzed }\end{array}$ & $\begin{array}{l}\text { A steep increase in pneumothorax rate noted when }>1.8 \mathrm{~L} \text { fluid } \\
(\mathrm{OR}, 3.8 ; \mathrm{Cl} 1.28-11.2) \text { and }>2.3 \mathrm{~L} \text { fluid }(\mathrm{OR}, 5.7 ; \mathrm{Cl}, 1.30-24.7) \\
\text { removed; amount of fluid removed also associated with higher risk } \\
\text { for chest tube placement }(P<0.0001)\end{array}$ \\
\hline & $\begin{array}{l}\text { Heidecker J, } \\
\text { et al }(2006)^{60}\end{array}$ & $\begin{array}{l}\text { Retrospective } \\
\text { chart review }\end{array}$ & 367 patients & $\begin{array}{l}\text { Charts reviewed of US-guided thoracenteses } \\
\text { performed with goal of explaining mechanism of } \\
\text { pneumothoraces that occurred }\end{array}$ & $\begin{array}{l}\text { Authors propose that the majority of pneumothoraces observed were } \\
\text { found to be related to unexpanded lung as opposed to direct trauma } \\
\text { or entranced air, and cannot be avoided with manometry }\end{array}$ \\
\hline \multirow[t]{4}{*}{$\begin{array}{l}\text { Postprocedure } \\
\text { imaging }\end{array}$} & $\begin{array}{l}\text { Jones P, et al } \\
(2003)^{62}\end{array}$ & $\begin{array}{l}\text { Prospective } \\
\text { cohort }\end{array}$ & $\begin{array}{l}605 \text { patients, } 941 \\
\text { thoracenteses }\end{array}$ & $\begin{array}{l}\text { Thoracenteses performed in the radiology department } \\
\text { under US guidance were analyzed to determine the } \\
\text { incidence of complications }\end{array}$ & $\begin{array}{l}\text { The complication rates of pneumothorax ( } 2.5 \%) \text {, hemothorax }(0.2 \%) \text {, } \\
\text { and REPE }(0.5 \%) \text { were low for US-guided thoracenteses performed } \\
\text { by interventional radiologists; these rates are less than the reported } \\
\text { rates for nonguided thoracentesis }\end{array}$ \\
\hline & $\begin{array}{l}\text { Petersen W, et al } \\
(2000)^{63}\end{array}$ & $\begin{array}{l}\text { Prospective } \\
\text { cohort }\end{array}$ & $\begin{array}{l}199 \text { patients, } 251 \\
\text { thoracenteses }\end{array}$ & $\begin{array}{l}\text { Physicians given questionnaire postprocedure rating } \\
\text { their concern for complication with CXR obtained at } \\
\text { doctor discretion; rate of pneumothorax }\end{array}$ & $\begin{array}{l}\text { Pneumothorax rate was } 2.7 \% \text { when there was no concern for } \\
\text { complication vs } 30 \% \text { when complication suspected; only procedural } \\
\text { risk factor associated with pneumothorax was aspiration of } \\
\text { air; recommend no CXR obtained unless clinical suspicion for } \\
\text { complication suspected }\end{array}$ \\
\hline & $\begin{array}{l}\text { Sachdeva A, } \\
\text { et al }(2014)^{64}\end{array}$ & Literature review & NA & $\begin{array}{l}\text { Review of relevant literature pertaining to US } \\
\text { exam techniques, thoracentesis, and an US-based } \\
\text { procedure service }\end{array}$ & $\begin{array}{l}\text { Bedside US has utility throughout the pre-, intra-, and postprocedure } \\
\text { process. It is a viable option for use to detect postprocedure } \\
\text { pneumothorax and is more sensitive than CXR }\end{array}$ \\
\hline & $\begin{array}{l}\text { Shostak E, et al } \\
(2013)^{65}\end{array}$ & $\begin{array}{l}\text { Prospective } \\
\text { cohort }\end{array}$ & 185 patients & $\begin{array}{l}\text { Bedside US exam performed on patients prior to and } \\
\text { after pleural procedures to detect pneumothorax }\end{array}$ & $\begin{array}{l}8 \text { pneumothoraces identified by CXR, } 7 \text { of which were seen on } \\
\text { bedside US; sensitivity was } 88 \% \text { and specificity } 97 \% \text {; bedside US is } \\
\text { a valuable tool to detect pneumothorax when a good quality scan is } \\
\text { obtained }\end{array}$ \\
\hline
\end{tabular}

NOTE: Abbreviations: Cl, confidence interval; CT, computed tomography; CXR, chest x-ray; ICA, intercostal artery; IM, internal medicine; INR, international normalized ratio; MICU, medical intensive care unit; OR, odds ratio; REPE, re-expansion pulmonary edema; US, ultrasound.

\section{Continued from page 269}

correlated with an unexpandable lung include a negative opening pressure ${ }^{47}$ and large fluctuations in pressure during the respiratory cycle..$^{54}$

While development of symptoms (eg, chest pain, cough, or dyspnea) is often used as a surrogate, the correlation between intrapleural pressure and patient symptoms is inconsistent and not a reliable proxy. ${ }^{55}$ One study found that $22 \%$ of patients with chest pain during thoracentesis had intrapleural pressures lower than $-20 \mathrm{~cm} \mathrm{H}_{2} \mathrm{O}$ compared with $8.6 \%$ of asymptomatic patients, ${ }^{56}$ but it is unclear if the association is causal.

Thoracentesis is often performed for symptomatic relief and removal of large fluid volume. However, it remains common to halt fluid removal after $1.5 \mathrm{~L}$, a threshold endorsed by BTS. ${ }^{19}$ While some investigators have suggested that removal of $2 \mathrm{~L}$ or more of pleural fluid does not compromise safety, ${ }^{57,58}$ a 4 - to 5 -fold rise in the risk of pneumothorax was noted in 2 studies. ${ }^{20,59}$ when more than $1.5 \mathrm{~L}$ of fluid was removed. The majority of these may be related to pneumothorax ex vacuo, a condition in which fluid is drained from the chest, but the lung is unable to expand and fill the space (eg, "trapped lung"), resulting in a persistent pneumothorax. This condition generally does not require treatment. ${ }^{60}$ When manometry is employed at $200-\mathrm{mL}$ intervals with termination at an intrapleural pressure of less than $20 \mathrm{~mm} \mathrm{H}_{2} \mathrm{O}$, drainage of $3 \mathrm{~L}$ or more has been reported with low rates of pneumothorax and very low rates of REPE. ${ }^{50,51}$ However, whether this is cause and effect is unknown because REPE is rare, and more work is needed to determine the role of manometry for its prevention.

\section{POSTPROCEDURAL CONSIDERATIONS Postprocedure Imaging}

Performing an upright CXR following thoracentesis is a practice that remains routinely done by many practitioners to monitor for complications. Such imaging was also endorsed by the American Thoracic Society guidelines. ${ }^{61}$ However, more recent data question the utility of this practice. Multiple studies have confirmed that post-thoracentesis CXR is unnecessary unless clinical suspicion for pneumothorax or REPE is present. ${ }^{36,58,62,63}$ The BTS guidelines also advocate this approach. ${ }^{19}$ Interestingly, a potentially more effective way to screen for postprocedure complications is through bedside US, which has been shown to be more sensitive than CXR in detecting pneumothorax. ${ }^{64}$ In 1 study of 185 patients, bedside US demonstrated a sensitivity of $88 \%$ and a specificity of $97 \%$ for diagnosing pneumothorax in patients with adequate quality scans, with positive and negative likelihood ratios of 55 and 0.17 , respectively. ${ }^{65}$

\section{DISCUSSION}

Thoracentesis remains a core procedural skill for hospitalists, critical care physicians, and emergency physicians. It is the foundational component when investigating and treating pleural effusions. When the most current training, techniques, and technology are used, data suggest this procedure is safe to perform at the bedside. Our review highlights these 
strategies and evaluates which aspects might be most applicable to clinical practice.

Our findings have several implications for those who perform this procedure. First, appropriate training is central to procedural safety, and both simulation and direct observation by procedural experts have been shown by multiple investigators to improve knowledge and skill. This training should integrate the use of US in performing a focused thoracic exam.

Second, recommendations regarding coagulopathy and a "safe cutoff" of an INR less than 1.5 or platelets greater than $50,000 / \mu \mathrm{L}$ had limited evidentiary support. Rather, multiple studies suggest no difference in bleeding risk following thoracentesis with an INR as high as 3.0 and platelets greater than $25,000 / \mu \mathrm{L}$. Furthermore, prophylactic transfusion with fresh frozen plasma or platelets before thoracentesis did not alter bleeding risk and exposes patients to transfusion complications. Thus, routine use of this practice can no longer be recommended. Third, further research is needed to understand the bleeding risk for patients on antiplatelet medications, heparin products, and also direct oral anticoagulants, given the growing popularity in their use and the potential consequences of even temporary cessation. Regarding patients on mechanical ventilation, thoracentesis demonstrated no difference in complication rates vs. the general population, and its performance in this population is encouraged when clinically indicated.

Intraprocedural considerations include the use of bedside US. Due to multiple benefits including effusion characterization, puncture site localization, and significantly lower rates of pneumothorax, the standard of care should be to perform thoracentesis with US guidance. Both use of US to mark an effusion immediately prior to puncture or in real time during needle insertion demonstrated benefit; however, it is unclear if 1 method is superior because no direct comparison studies were found. Further work is needed to investigate this potential.

Our review suggests that the location and course of the ICA is variable, especially near the midline, in the elderly, and in higher intercostal spaces, leaving it vulnerable to laceration. We recommend physicians only attempt thoracentesis at least $6 \mathrm{~cm}$ lateral to the midline due to ICA tortuosity and, ideally, $12 \mathrm{~cm}$ lateral, to avoid the presence of collaterals. Although only 2 small-scale studies were found pertaining to the use of US in identifying the ICA, we encourage physicians to consider learning how to screen for its presence as a part of their routine thoracic US exam in the area underlying the planned puncture site.

Manometry is beneficial because it can diagnose a nonexpandable lung and allows for pleural pressure monitoring. ${ }^{52,53} \mathrm{~A}$ simple U-shaped manometer can be constructed from intravenous tubing included in most thoracentesis kits, which adds little to overall procedure time. While low rates of REPE have been observed when terminating thoracentesis if pressures drop below $-20 \mathrm{~cm} \mathrm{H}_{2} \mathrm{O}$ or chest pain develops, neither measure appears to have reliable predictive value, limiting clinical utility. Further work is required to determine if a "safe pressure cutoff" exists. In general, we recommend the use of manometry when a nonexpandable (trapped) lung is suspected, because large drops in intrapleural pressure, a negative opening pressure, and respiratory variation can help confirm the diagnosis and avoid pneumothorax ex vacuo or unnecessary procedures in the future. As this condition appears to be more common in the setting of larger effusions, use of manometry when large-volume thoracenteses are planned is also reasonable.

Postprocedurally, routine imaging after thoracentesis is not recommended unless there is objective concern for complication. When indicated, bedside US is better positioned for this role compared with CXR, because it is more sensitive in detecting pneumothorax, provides instantaneous results, and avoids radiation exposure.

Our review has limitations. First, we searched only for articles between defined time periods, restricted our search to a single database, and excluded non-English articles. This has the potential to introduce selection bias, as nonprimary articles that fall within our time restrictions may cite older studies that are outside our search range. To minimize this effect, we performed a critical review of all included studies, especially nonprimary articles. Second, despite the focus of our search strategy to identify any articles related to patient safety and adverse events, we cannot guarantee that all relevant articles for any particular complication or risk factor were captured given the lack of more specific search terms. Third, although we performed a systematic search of the literature, we did not perform a formal systematic review or formally grade included studies. As the goal of our review was to categorize and operationalize clinical aspects, this approach was necessary, and we acknowledge that the quality of studies is variable. Lastly, we aimed to generate clinical recommendations for physicians performing thoracentesis at the bedside; others reviewing this literature may find or emphasize different aspects relevant to practice outside this setting.

In conclusion, evaluation and treatment of pleural effusions with bedside thoracentesis is an important skill for physicians of many disciplines. The evidence presented in this review will help inform the process and ensure patient safety. Physicians should consider incorporating these recommendations into their practice.

\section{Acknowledgments}

The authors thank Whitney Townsend, MLIS, health sciences informationist, for assistance with serial literature searches.

Disclosure: Nothing to report.

\section{References}

1. Kasper DL. Harrison's Principles of Internal Medicine. 19th ed. New York, NY: McGraw Hill Education; 2015.

2. Celik B, Sahin E, Nadir A, Kaptanoglu M. Iatrogenic pneumothorax: etiology, incidence and risk factors. Thorac Cardiovasc Surg. 2009;57(5):286-290.

3. Hooper CE, Welham SA, Maskell NA, Soc BT. Pleural procedures and patient 
safety: a national BTS audit of practice. Thorax. 2015;70(2):189-191.

4. Diacon $\mathrm{AH}$, Brutsche $\mathrm{MH}$, Soler M. Accuracy of pleural puncture sites: a prospective comparison of clinical examination with ultrasound. Chest. 2003;123(2): 436-441.

5. Patel IJ, Davidson JC, Nikolic B, et al. Consensus guidelines for periprocedural management of coagulation status and hemostasis risk in percutaneous image-guided interventions. J Vasc Interv Radiol. 2012;23(6):727-736.

6. Wraight WM, Tweedie DJ, Parkin IG. Neurovascular anatomy and variation in the fourth, fifth, and sixth intercostal spaces in the mid-axillary line: a cadaveric study in respect of chest drain insertion. Clin Anat. 2005;18(5):346-349.

7. Duncan DR, Morgenthaler TI, Ryu JH, Daniels CE. Reducing iatrogenic risk in thoracentesis: establishing best practice via experiential training in a zero-risk environment. Chest. 2009;135(5):1315-1320.

8. Grover S, Currier PF, Elinoff JM, Mouchantaf KJ, Katz JT, McMahon GT. Development of a test to evaluate residents' knowledge of medical procedures. J Hosp Med. 2009;4(7):430-432

9. Promes SB, Chudgar SM, Grochowski CO, et al. Gaps in procedural experience and competency in medical school graduates. Acad Emerg Med. 2009;16 Suppl 2:S58-62.

10. Huang GC, Smith CC, Gordon CE, et al. Beyond the comfort zone: residents assess their comfort performing inpatient medical procedures. Am J Med. 2006;119(1):71 e17-24

11. Lagan J, Cutts L, Zaidi S, Benton I, Rylance J. Are we failing our trainees in providing opportunities to attain procedural confidence? Br J Hosp Med (Lond). 2015;76(2):105-108.

12. Wayne DB, Barsuk JH, O'Leary KJ, Fudala MJ, McGaghie WC. Mastery learning of thoracentesis skills by internal medicine residents using simulation technology and deliberate practice. J Hosp Med. 2008;3(1):48-54.

13. Lenchus JD. End of the "see one, do one, teach one" era: the next generation of invasive bedside procedural instruction. J Am Osteopath Assoc. 2010;110(6): 340-346.

14. Lenchus J, Issenberg SB, Murphy D, et al. A blended approach to invasive bedside procedural instruction. Med Teach. 2011;33(2):116-123.

15. Jiang $G$, Chen $H$, Wang $S$, et al. Learning curves and long-term outcome of simulation-based thoracentesis training for medical students. BMC Med Educ. 2011;11:39.

16. Berg D, Berg K, Riesenberg LA, et al. The development of a validated checklist for thoracentesis: preliminary results. Am J Med Qual. 2013;28(3):220-226.

17. Salamonsen M, McGrath D, Steiler G, Ware R, Colt H, Fielding D. A new in strument to assess physician skill at thoracic ultrasound, including pleural effusion markup. Chest. 2013;144(3):930-934.

18. McVay PA, Toy PT. Lack of increased bleeding after paracentesis and thoracentesis in patients with mild coagulation abnormalities. Transfusion. 1991;31(2): 164-171.

19. Havelock T, Teoh R, Laws D, Gleeson F, Group BTSPDG. Pleural procedure and thoracic ultrasound: British Thoracic Society Pleural Disease Guideline 2010. Thorax. 2010;65 Suppl 2:ii61-76.

20. Ault MJ, Rosen BT, Scher J, Feinglass J, Barsuk JH. Thoracentesis outcomes: 12-year experience. Thorax. 2015;70(2):127-132.

21. Puchalski J. Thoracentesis and the risks for bleeding: a new era. Curr Opin Pulm Med. 2014;20(4):377-384

22. Hibbert RM, Atwell TD, Lekah A, et al. Safety of ultrasound-guided thoracentesis in patients with abnormal preprocedural coagulation parameters. Chest 2013;144(2):456-463.

23. Zalt MB, Bechara RI, Parks C, Berkowitz DM. Effect of routine clopidogrel use on bleeding complications after ultrasound-guided thoracentesis. J Bronchology Interv Pulmonol. 2012;19(4):284-287.

24. Mahmood K, Shofer SL, Moser BK, Argento AC, Smathers EC, Wahidi MM Hemorrhagic complications of thoracentesis and small-bore chest tube placement in patients taking clopidogrel. Ann Am Thorac Soc. 2014;11(1):73-79.

25. Goligher EC, Leis JA, Fowler RA, Pinto R, Adhikari NK, Ferguson ND. Utility and safety of draining pleural effusions in mechanically ventilated patients: a systematic review and meta-analysis. Crit Care. 2011;15(1):R46.

26. Fartoukh M, Azoulay E, Galliot R, et al. Clinically documented pleural effusions in medical ICU patients: how useful is routine thoracentesis? Chest 2002;121(1):178-184

27. Cervini P, Hesley GK, Thompson RL, Sampathkumar P, Knudsen JM. Incidence of infectious complications after an ultrasound-guided intervention. AJR Am J Roentgenol. 2010;195(4):846-850.

28. Mimoz O, Chopra V, Timsit JF. What's new in catheter-related infection: skin cleansing and skin antisepsis. Intensive Care Med. 2016;42(11):1784-1786.

29. Soni NJ, Franco R, Velez MI, et al. Ultrasound in the diagnosis and management of pleural effusions. J Hosp Med. 2015;10(12):811-816.

30. Feller-Kopman D. Ultrasound-guided thoracentesis. Chest. 2006;129(6): $1709-1714$
31. Shojaee S, Argento AC. Ultrasound-guided pleural access. Semin Respir Crit Care Med. 2014:35(6):693-705

32. Gordon CE, Feller-Kopman D, Balk EM, Smetana GW. Pneumothorax following thoracentesis: a systematic review and meta-analysis. Arch Intern Med. 2010;170(4):332-339

33. Perazzo A, Gatto P, Barlascini C, Ferrari-Bravo M, Nicolini A. Can ultrasound guidance reduce the risk of pneumothorax following thoracentesis? J Bras Pneumol. 2014;40(1):6-12

34. Cavanna L, Mordenti P, Berte R, et al. Ultrasound guidance reduces pneumothorax rate and improves safety of thoracentesis in malignant pleural effusion: report on 445 consecutive patients with advanced cancer. World J Surg Oncol. 2014;12:139

35. Soldati G, Smargiassi A, Inchingolo R, Sher S, Valente S, Corbo GM. Ultrasound-guided pleural puncture in supine or recumbent lateral position - feasibility study. Multidiscip Respir Med. 2013;8(1):18

36. Pihlajamaa K, Bode MK, Puumalainen T, Lehtimaki A, Marjelund S, Tikkakoski T. Pneumothorax and the value of chest radiography after ultrasound-guided thoracocentesis. Acta Radiol. 2004;45(8):828-832.

37. Barnes TW, Morgenthaler TI, Olson EJ, Hesley GK, Decker PA, Ryu JH. Sonographically guided thoracentesis and rate of pneumothorax. J Clin Ultrasound. 2005;33(9):442-446.

38. Zanforlin A, Gavelli G, Oboldi D, Galletti S. Ultrasound-guided thoracenthesis: the V-point as a site for optimal drainage positioning. Eur Rev Med Pharmacol Sci. 2013;17(1):25-28.

39. Patel PA, Ernst FR, Gunnarsson CL. Ultrasonography guidance reduces complications and costs associated with thoracentesis procedures. J Clin Ultrasound. 2012;40(3):135-141.

40. Mercaldi CJ, Lanes SF. Ultrasound guidance decreases complications and improves the cost of care among patients undergoing thoracentesis and paracentesis. Chest. 2013;143(2):532-538.

41. Shurtleff E, Olinger A. Posterior intercostal artery tortuosity and collateral branch points: a cadaveric study. Folia Morphol (Warsz). 2012;71(4):245-251.

42. Helm EJ, Rahman NM, Talakoub O, Fox DL, Gleeson FV. Course and variation of the intercostal artery by CT scan. Chest. 2013;143(3):634-639.

43. Yoneyama H, Arahata M, Temaru R, Ishizaka S, Minami S. Evaluation of the risk of intercostal artery laceration during thoracentesis in elderly patients by using 3D-CT angiography. Intern Med. 2010;49(4):289-292.

44. Salamonsen M, Ellis S, Paul E, Steinke K, Fielding D. Thoracic ultrasound demonstrates variable location of the intercostal artery. Respiration. 2012;83(4):323-329.

45. Salamonsen M, Dobeli K, McGrath D, et al. Physician-performed ultrasound can accurately screen for a vulnerable intercostal artery prior to chest drainage procedures. Respirology. 2013;18(6):942-947

46. Grippi MA. Fishman's pulmonary diseases and disorders. 5th ed. New York, NY: McGraw-Hill Education; 2015.

47. Huggins JT, Doelken P. Pleural manometry. Clin Chest Med. 2006;27(2):229-240.

48. Echevarria C, Twomey D, Dunning J, Chanda B. Does re-expansion pulmonary oedema exist? Interact Cardiovasc Thorac Surg. 2008;7(3):485-489.

49. Sue RD, Matthay MA, Ware LB. Hydrostatic mechanisms may contribute to the pathogenesis of human re-expansion pulmonary edema. Intensive Care Med. 2004;30(10):1921-1926.

50. Feller-Kopman D, Berkowitz D, Boiselle P, Ernst A. Large-volume thoracentesis and the risk of reexpansion pulmonary edema. Ann Thorac Surg. 2007;84(5): 1656-1661.

51. Villena V, Lopez-Encuentra A, Pozo F, De-Pablo A, Martin-Escribano P. Measurement of pleural pressure during therapeutic thoracentesis. Am J Respir Crit Care Med. 2000;162(4 Pt 1):1534-1538.

52. Doelken P, Huggins JT, Pastis NJ, Sahn SA. Pleural manometry: technique and clinical implications. Chest. 2004;126(6):1764-1769.

53. Feller-Kopman D. Therapeutic thoracentesis: the role of ultrasound and pleural manometry. Curr Opin Pulm Med. 2007;13(4):312-318.

54. Boshuizen RC, Sinaasappel M, Vincent AD, Goldfinger V, Farag S, van den Heuvel MM. Pleural pressure swing and lung expansion after malignant pleural effusion drainage: the benefits of high-temporal resolution pleural manometry. $J$ Bronchology Interv Pulmonol. 2013;20(3):200-205.

55. Pannu J, DePew ZS, Mullon JJ, Daniels CE, Hagen CE, Maldonado F. Impact of pleural manometry on the development of chest discomfort during thoracentesis: a symptom-based study. J Bronchology Interv Pulmonol. 2014;21(4):306-313.

56. Feller-Kopman D, Walkey A, Berkowitz D, Ernst A. The relationship of pleural pressure to symptom development during therapeutic thoracentesis. Chest. 2006;129(6):1556-1560.

57. Abunasser J, Brown R. Safety of large-volume thoracentesis. Conn Med. 2010;74(1):23-26.

58. Mynarek G, Brabrand K, Jakobsen JA, Kolbenstvedt A. Complications following ultrasound-guided thoracocentesis. Acta Radiol. 2004;45(5):519-522.

59. Josephson T, Nordenskjold CA, Larsson J, Rosenberg LU, Kaijser M. Amount 
drained at ultrasound-guided thoracentesis and risk of pneumothorax. Acta Radiol. 2009;50(1):42-47.

60. Heidecker J, Huggins JT, Sahn SA, Doelken P. Pathophysiology of pneumothorax following ultrasound-guided thoracentesis. Chest. 2006;130(4):1173-1184.

61. Sokolowski JW Jr, Burgher LW, Jones FL Jr, Patterson JR, Selecky PA. Guidelines for thoracentesis and needle biopsy of the pleura. This position paper of the American Thoracic Society was adopted by the ATS Board of Directors, June 1988. Am Rev Respir Dis. 1989;140(1):257-258.
62. Jones PW, Moyers JP, Rogers JT, Rodriguez RM, Lee YC, Light RW. Ultrasound-guided thoracentesis: is it a safer method? Chest. 2003;123(2):418-423.

63. Petersen WG, Zimmerman R. Limited utility of chest radiograph after thoracentesis. Chest. 2000;117(4):1038-1042.

64. Sachdeva A, Shepherd RW, Lee HJ. Thoracentesis and thoracic ultrasound: state of the art in 2013. Clin Chest Med. 2013;34(1):1-9.

65. Shostak E, Brylka D, Krepp J, Pua B, Sanders A. Bedside sonography for detection of postprocedure pneumothorax. J Ultrasound Med. 2013;32(6):1003-1009. 